\title{
Short-Term Memory Training of Students during Foreign Language Learning
}

\author{
Olena Bratel ${ }^{1}$, Maryna Kostiuk ${ }^{1}$, Sergiy Bratel' ${ }^{2}$ Ivan Okhrimenko ${ }^{3, *}$, Volodymyr Filonenko ${ }^{4}$ \\ ${ }^{1}$ Department of Roman Philology, Institute of Philology, National Taras Shevchenko University of Kyiv, Kyiv, 01601, Ukraine \\ ${ }^{2}$ Department of Police Law, National Academy of Internal Affairs, Kyiv, 03035, Ukraine \\ ${ }^{3}$ Department of Legal Psychology, National Academy of Internal Affairs, Kyiv, 03035, Ukraine \\ ${ }^{4}$ Department of Sociology and Psychology, Kharkiv National University of Internal Affairs, Kharkiv, 61000, Ukraine
}

Received January 22, 2020; Revised March 19, 2020; Accepted March 28, 2020

Copyright $\odot 2020$ by authors, all rights reserved. Authors agree that this article remains permanently open access under the terms of the Creative Commons Attribution License 4.0 International License

\begin{abstract}
Research is dedicated to short-term memory training for university students specializing in translation and interpreting. The purpose of the study was to consider the possibilities of increasing short-term memory capacity of the students who study French by regular training during their language classes. To check short-term memory capacity, a method of random reproduction was chosen. It is an experimental method based on a list of words that respondents have to reproduce in a random order after hearing them. The words for the tests were chosen on the basis of their usage, imagery, the effect of phonological similarity and the effect of the length of the word. During testing, the physiological state of the respondents, their age and the speed of the teacher's reading were taken into consideration. To train short-term memory in French language classes, special tasks were created, and students performed them as part of class activities over a period of two months. The experiment showed that short-term memory training for students is effective and can be recommended for foreign language classes. The result of the experiment demonstrated significant growth in the short-term memory capacity of the students.
\end{abstract}

Keywords Short-term Memory, Memory Training, Foreign Languages, Students

\section{Introduction}

Researchers' interest in memory arose long ago as evidenced by Plato (Greek philosopher, 427-347 B.C.) who metaphorically called memory a wax board in the person's soul that keeps the image of everything we see or hear: "The waxen block in the heart of a man's soul... may be smooth and deep, and large enough, and then the signs are clearly marked and lasting" [1]. The explosion of information in society requires searching for new methods of memory analysis, in particular the peculiarities of perception, treatment, retaining or producing information. Since the amount of information confronting people every day is constantly growing, modern researchers are interested in the possibility of improving memorizing and increasing memory capacity $[2,3,4,5]$.

Information received by a person initially goes into short-term memory [6] that is, "faculties of the human mind that can hold a limited amount of information in a very accessible state temporarily" [7]. Short-term memory is a part of the work memory system that is able not only to keep information but also to use it, and permits logical thinking, learning and comprehension. The ability of a person to memorize something depends on the speed of functioning of the short-term memory: the quicker it works, the better the ability to remember. The capacity of short-term memory differs in individuals and characterizes the natural memory of a person, the essence of which is the capacity to automatically memorize without usage of any special techniques [2].

There are some professional activities, the successful accomplishment of which depends on short-term memory capacity and the speed of its functioning. For example, short-term memory is essential for the effective work of interpreters who constantly deal with situations where they need to memorize some information on the spot and reproduce it in a foreign language. During oral translation, the parts of the brain that control speaking and comprehension are activated, as well as the part of the brain that is known as the Broca area responsible for the processes of speaking and short-term memory that permits thinking and acting at the same time [8]. That is why during interpreting, especially in the case of the simultaneous one, when an interpreter has to listen, translate and speak at 
once, the importance of speed of short-term memory functioning increases. For consecutive interpreting the capacity of short-term memory is essential, as it allows remembering big chunks of information and reconstructing the expected information from the context [9]. As the capacity and speed of short-term memory are very important elements in the work of interpreters, research dedicated to short-term memory training for university students specializing in interpreting will be of great value in modern memory studies.

During the last fifteen years, the Ukrainian researchers have been especially interested in improving the training of students majoring in translation and interpreting. For example, in Ukraine the $\mathrm{PhD}$ papers were written about individual style of professional communication, readiness for professional creative activity, professional communicative competence, and intercultural competence. At the same time, the problem of memory development in the interpreters' training has not received sufficient attention from the Ukrainian researchers.

\subsection{The Aim}

As well-developed short-term memory is a significant component in the work of professional interpreters, it can have a positive impact on the competitiveness of young professionals when they graduate from university.

Taking into consideration modern approaches to the learning and teaching of foreign languages, it's incumbent upon teachers to train the short-term memory of students specializing in a foreign language, literature, translation and interpreting, because increasing short-term memory capacity and speed will improve their skills of simultaneous and consequent interpreting.

We hypothesized that short-term memory capacity of students can be increased by regular memory training in the process of traditional university studies of various subjects. In particular, we decided to develop memory training activities during foreign language classes, particularly French classes, and created series of tasks appropriate for language classes that help to develop memorization skills. It was also our hypothesis that short-term memory capacity of students with a less than one year of university formation (the first year students) and students with more than three years of university formation (the fourth year students) is approximately the same, and that it can be increased after special memory training.

So, the purpose of our research work was to check the possibilities of increasing short-term memory capacity by regular training as a way to improve interpreting skills.

\subsection{Tasks}

In order to achieve this purpose, these tasks were set:

- to examine short-term memory capacity of the first and fourth year students before the experiment;
- $\quad$ to offer some tasks of short-term memory training during foreign language classes;

- to compare short-term memory capacity before and after short-term memory training.

\section{Materials and Methods}

\subsection{Participants}

Before the beginning of the research, a preliminary study of the general population of students who study at the Romance Languages Department of the Philology Institute of Taras Shevchenko National University of Kyiv was made. There are students of the first, the second, the third and the fourth years of undergraduate studies at the Department, majoring in French translation and interpreting. There are 3 groups in every year of studies, with 9-12 students in each group. The division of students into the groups took place during the university admission process and was conducted by the Faculty Team before enrolling students for studies without stating any criteria for such division, except for students' desire to learn a certain language. Thus, the total number of 130 students who wanted to major in French translation and interpreting was randomly divided into 12 groups at the beginning of the first year of their studies at University.

In order to ensure the representativeness and proper quality of the research results, it was decided that the sample of the study would be $50 \%$ of all students majoring in French translation and interpreting. In particular, three first year academic groups were selected for the study (one group of students studying French and English, one group of students studying French and Arabic, and one group of students studying French and Vietnamese) and three similar academic groups of fourth year students were selected as well. No special selection of students was carried out by the authors of the article. In total, 62 students participated in the study: 32 first year students and 30 fourth year students. These groups were selected to measure short-term memory capacity of young people who have just entered the university and students who already have had three years of university studies, and to test effectiveness of the memory training according to different levels of students' preparation.

Students who enter Taras Shevchenko National University of Kyiv with a major in French translation and interpreting may have different levels of French at the beginning of the first year of studies, usually ranging from the level A1 to the level B2. At the beginning of the fourth year of studies, the level of French usually reaches the levels C1-C2. At the university, French classes are held according to the students' level of a foreign language. For our study, students were not selected according to their language proficiency.

At the stage of word selection for our testing, we took 
into account the fact of multilevel student preparation, so we used the words corresponding to A1-A2 levels according to Common European Framework of Reference for Languages, so that for fourth year and first year students, these words were already familiar.

\subsection{Research Procedure}

The research consisted of two stages: first, testing short-term memory capacity of students and assessing the results, followed by regular training of short-term memory; second, testing and assessing the results and comparing the results of both tests, and revising conclusions.

The experiment was based on the scientific prediction that short-term memory capacity can be developed by means of special regular training. Our study included initial and formative stages of the experiment that were conducted under conditions of the pedagogical process of the Romance Philology Department of the Philology Institute of Taras Shevchenko National University of Kyiv.

The initial stage of the experiment was aimed at establishing the students' short-term memory capacity at the beginning of the research. On the basis of the collected data, the tasks of the study were specified; the methodology of memory training was developed and adjusted. Several interrelated research methods were used to obtain objective data during the initial stage of the experiment. The observation method was chosen as the main one for the collection of facts. It was supplemented by conversations with students and questionnaires, and these data were taken into account during the formative stage of the experiment.

The study started with testing of short-term memory capacity of the first and the fourth year students using a list of such 10 French words: une chaise, une maison, un cahier, un pirate, un amour, une table, un ballon, une microscope, une fleur, un stylo.

Next came the training of short-term memory. For this purpose, French writers' poems and humorous short stories were read aloud. Then, students were to repeat what they heard as closely to the reading as possible. This was done twice a week for a period of two months.

So, the first task was the exact repetition of each line of a poem perceived by ear [10]. Working with the poetry had several steps. First, students repeated every single line of the poem their teacher read, and then they tried to repeat two lines at a time of the same poem. Students were given two types of listening tests: the teacher read the poem, pausing at the end of every line, or the teacher switched to an audio recording of the poem and stopped it in necessary places.

The movement and rhyme of poetry have a positive impact on the process of memorization and production. Therefore, for training of short-term memory, different poems with distinct rhythm, rhyme and melodiousness were chosen, e.g., poems of French poet Paul Verlaine "Chanson d'automne", "Le ciel est par-dessus le toit",
"Mon rêve familier" [11]. For the memory training tasks the poems of Arthur Rimbaud, Stéphan Mallarmé and other French writers were used [12].

Before beginning short-term memory training, some main techniques of poetry analysis were explained: the students became familiar with the text of poems, their lexical, grammatical and phonetic aspects, determined the structure of rhyming, translated the unknown words and worked on the meaning of some new grammatical structures. The initial work with a poem is especially important for those students who learn French during the first or second year where a lot of unknown lexical and grammatical units can significantly decrease the effective memorization of the text and its producing.

The second task to train short-term memory was producing close to text some short funny stories or anecdotes. The use of such texts during the lessons, besides mechanical training of the memory, induces a relaxing atmosphere and helps calm students, which also improves memorization [2].

These two types of tasks offered for short-term memory training also help to improve the linguistic and cultural competence of students. Poems and short stories introduce students to cultural matters and reinforce familiar lexical and grammatical units, and also ease the fear of unknown lexical units, all of which improve memorization.

After two months of the regular work on short-term memory training, the second testing took place, and another list of 10 words was read to the students (une tasse, un lit, une fenêtre, une chance, un pont, une guitare, une porte, un coussin, une lampe, un café).

On the basis of the results of the initial stage of the experiment, the formative stage of the experiment was organized, during which the students' memory after appropriate training was studied. In such way the effectiveness of the short-term memory training methodology was tested. For this purpose, a special training with the use of tasks aimed at short-term memory development was organized. The data of the formative stage of the experiment were summarized in the form of tables, and the conclusions were drawn.

Thus, short-term memory capacity of the first and the fourth year students was studied at the beginning of the research, and then short-term memory regular training sessions were conducted with the students using the methods developed by the authors. To test the effectiveness of the memory training, the second testing of short-term memory capacity of the same groups of students took place.

\subsection{Research Methodology}

Short-term memory capacity can be checked by doing tasks that require keeping in memory a certain amount of information, and the capacity of short-term memory is checked immediately after accomplishing specified tasks. 
To check the short-term memory capacity of students who learn foreign languages, a method of random reproduction was chosen. It is an experimental method based on a list of words that respondents have to produce in a random order after hearing the words [13].

During the testing of the capacity of short-term memory, students heard 10 words in French read by a teacher and then they wrote down the words they could recollect. During the first testing those French words were: une chaise, une maison, un cahier, un pirate, un amour, une table, un ballon, une microscope, une fleur, un stylo. To check the capacity of short-term memory of the students after regular training, these French words were used: une tasse, un lit, une fenêtre, une chance, un pont, une guitare, un coussin, une porte, une lampe, un café.

For easier understanding of the tests' results, the capacity of short-term memory was divided into three levels: low (4 words), middle (5-7 words) and high (8-9 words).

When lexical units were chosen for the experiment, common words and words easily visualized were used because they are more readily remembered [13], therefore 9 out of the 10 words used in the tests could have been visualized. The words were chosen from the ones that students were supposed to be familiar with according to the syllabus, for the very reason that the use of unfamiliar words can significantly influence the results.

For the first and the second testing of the capacity of short-term memory, students heard a list of 10 French words of general usage that they were supposed to learn during French classes in the first semester, among which were words that compose pairs (une table - une chaise, un stylo - un cahier, une tasse - un café, un lit - un coussin) two pairs for every 10 words. Also every 10 words include 3 words that are not connected to any of the words in the list (une maison, un ballon, une fleur, une fenêtre, une porte, une lampe). One abstract term (un amour, une chance) and two words outside the general category of words (une microscope, un pirate, un pont, une guitare) are also included in both lists (Table 1).

When choosing the vocabulary for the experiment, the effect of phonological resemblance was taken into account. Phonological resemblance impacts the recollection of language material, when the words sound similar. This effect is very important as the ability to memorize words with similar letters is usually more difficult. Hence, it is easier to memorize a list of five words that do not resemble each other than a list of phonologically similar words. Interestingly, words which are similar in meaning are not more difficult to memorize than those with different meanings. It should be mentioned that the effect of phonological resemblance lessens with the longer list of words and when respondents are tested several times; in this case the resemblance in the meaning becomes more important [13]. To minimize the effect of phonological resemblance, words not similar to each other have been chosen.

Table 1. Peculiarities of the nouns chosen for testing

\begin{tabular}{|l|c|}
\hline Peculiarities of the nouns & $\begin{array}{l}\text { Number of nouns (in } \\
\text { each test) }\end{array}$ \\
\hline Nouns that form pairs & 4 \\
\hline Nouns that are not related to each other & 3 \\
\hline $\begin{array}{l}\text { Nouns that fall out of the general } \\
\text { category of words }\end{array}$ & 2 \\
\hline Abstract nouns & 1 \\
\hline
\end{tabular}

In addition, when choosing words for the tests, the effect of a word's length was considered as memory capacity decreases when the length of the words increases. Most people can quite easily remember a sequence of five monosyllabic words that do not resemble each other. With the increasing of word length, the number of correct answers decreases from $90 \%$ for five monosyllabic words to $50 \%$ for the list of words of five syllables [13]. Therefore, words of one and two syllables were selected for the experiment.

The physical state of students can affect the memorizing of words (for instance, alcohol can have a negative impact on the results). Therefore, before administering the test, the teacher made sure that the physiological and psychological states of the students were satisfactory and that students were in proper condition for the experiment.

Repeating words can also be influenced by the reading speed (the slower the better) [13]. Peculiarities of pronunciation in a foreign language, in our case, French, known for its difficult phonetics, is an additional factor. So, for reading the words for the tests the students own, teachers were chosen for the experiment to eliminate unfamiliar accents. Moreover, teachers read with the speed that students were accustomed to, taking into consideration their level of French.

Since respondents' age can affect the results of the research, a group of students of similar age (17-21 years old) was chosen - and that age is typical for students in Ukraine. (For example, middle age people can memorize more words than children or the elderly). One of the neurophysiological peculiarities connected with the development of the central nervous system of the mentioned age is that it is characterized by the biggest capacity of short-term visual and sound modality in comparison to other adult age groups [14].

In our study, a systematic approach to collect and evaluate data was used, as well as a number of scientific research methods. In particular, groups of students were subjected to initial and formative stages of the experiment, during which they were interviewed and observed in order to take into account their physiological and psychological state, as it could significantly affect students' memory efficiency. In addition, during different stages of the experiment, not only the analysis and comparison of the 
data of the initial and final results of the whole group of students, but also the data of students of different years of studies were made.

\subsection{Data Analysis}

To process the quantitative expressions of the empirical data obtained during the study and to assess the dynamics and the reliability of the results, a method of mathematical statistics was used during the first and second testing of the short-term memory capacity of students' learning French. In particular, descriptive statistics were applied that allowed to make grouping and graphical expression of the results of the research.

Thus, the article presents data obtained from descriptive statistics aimed at properties of the observed data and not at the assumption that these data come from a large population.

Our research involved studying the short-term memory capacity of the first and fourth year students majoring in French translation and interpreting by counting the number of words students memorized during the experiment and dividing students into conventional groups according to their short-term memory capacity. In our opinion, the descriptive statistics is quite sufficient for such a study. Thus, after processing and organizing the empirical data, we have presented it in a descriptive way and formulated it in tables.

At the same time, we assume that the data obtained may be considered true for the second and the third year students majoring in French translation and interpreting. In our next research, we plan to test this hypothesis, as well as the hypothesis whether the results of our study can be relevant for students of the Romance Languages Department of the Philology Institute of Taras Shevchenko National University of Kyiv majoring in other foreign languages, as well as for the students studying in other educational institutions.

\subsection{Ethical Approval}

The study was performed in accordance with the requirements and provisions of the University Community Ethics Code of Taras Shevchenko National University of Kyiv, which was developed on the basis of Ukrainian and world ethical rulemaking experience and recommendations of experts taking into account the proposals of the University structural units, and agreed with the student self-government, trade unions and other public organizations [15]. This document was approved at the Labor Conference of Taras Shevchenko National University of Kyiv (Minutes No. 2 dated December 27, 2017). Members of the university community are guided by the principles of the academic freedom -independence of the community members in obtaining and using knowledge and information, in conducting researches and applying their results, as well as by the academic integrity
- advocating honesty, justice, respect, responsibility, ethical principles and laws in scientific (creative) activity to establish confidence in the results of scientific (creative) achievements [15].

\section{Results}

The time short-term memory retains information is limited and very short; if memories are not somehow supported, they can be forgotten in several seconds and the highest possible duration of short-term memory is 20-30 seconds [16]. The short-term memory capacity of most people is $7 \pm 2$ units, if they deal with the memorization and producing of 10 words, numbers, pictures etc. that are extracted from the context $[16,17]$. Thus, the usual capacity of short-term memory is 5-7 objects [2]. If the quantity of objects for memorization is increased, however, and respondents are asked to memorize and reproduce 30 words, they will recollect $10-15$ [4] that is $30-50 \%$ from the general quantity of words.

During the first testing of short-term memory capacity of the first and fourth year students, such 10 French words were used: une chaise, une maison, un cahier, un pirate, un amour, une table, un ballon, une microscope, une fleur, un stylo.

So, the results of the first testing of short-term memory capacity of the first year students were as following: 6 persons produced 4 words (19\%), 8 persons -5 words (25\%), 9 persons -6 words $(28 \%), 6$ persons -7 words $(19 \%)$, and 3 persons -8 words $(9 \%)$. The fourth year students showed these results: 2 persons produced 4 words (7\%), 6 persons -5 words $(20 \%), 8$ persons -6 words (26\%), 9 persons -7 words $(30 \%), 3$ persons -8 words (10\%), and 2 persons -9 words (7\%) (Table 2).

Table 2. Number of words remembered by the first and the fourth year students during the first short-term memory capacity testing

\begin{tabular}{|c|c|c|}
\hline $\begin{array}{c}\text { Number of words } \\
\text { remembered by the } \\
\text { students }\end{array}$ & $\begin{array}{c}\text { The first year } \\
\text { students }\end{array}$ & $\begin{array}{c}\text { The fourth year } \\
\text { students }\end{array}$ \\
\hline 4 words & 6 persons $(19 \%)$ & 2 persons $(7 \%)$ \\
\hline 5 words & 8 persons $(25 \%)$ & 6 persons $(20 \%)$ \\
\hline 6 words & 9 persons $(28 \%)$ & 8 persons $(26 \%)$ \\
\hline 7 words & 6 persons $(19 \%)$ & 9 persons $(30 \%)$ \\
\hline 8 words & 3 persons $(9 \%)$ & 3 persons $(10 \%)$ \\
\hline 9 words & 0 persons & 2 persons $(7 \%)$ \\
\hline
\end{tabular}

Thus, 6 students of the first year of studies (19\%) showed low level of short-term memory, 23 persons (72\%) - middle level of short-term memory, and 3 persons (9\%) high level of short-term memory. The results of testing of the fourth year students were next: 2 persons (7\%) showed a low level of short-term memory, 23 persons $(76 \%)-$ 
middle, and 5 persons (17\%) - high (Table 3).

The first testing showed that the fourth year students had a higher capacity of short-term memory than the first year students [14]. Fourth year students clearly benefitted from the extra memory training of more than three years in the university French program in comparison with the first year students.

Table 3. The comparison of the capacity of short-term memory of the first and fourth year students in the first testing (\%)

\begin{tabular}{|c|c|c|c|}
\hline \multirow{2}{*}{ Group of students } & \multicolumn{3}{|c|}{ Levels of short-term memory } \\
\cline { 2 - 4 } & Low & Middle & High \\
\hline The first year students & $19 \%$ & $72 \%$ & $9 \%$ \\
\hline The fourth year students & $7 \%$ & $76 \%$ & $17 \%$ \\
\hline
\end{tabular}

Thus, the first testing demonstrated that more fourth year students than first year students had a high level of short-term memory capacity, while more first year students than fourth year students had a low level of short-term memory capacity.

After two months of regular short-term memory training sessions, the second testing with the following word list was held: une tasse, un lit, une fenetre, une chance, un pont, une guitare, une porte, un cousin, une lampe, un café.

The first year students' results of the second testing were: 4 words were produced by 3 persons (9\%), 5 words - by 8 persons (25\%), 6 words - by 9 persons (28\%), 7 words - by 8 persons $(25 \%)$, and 8 words - by 4 persons (12\%). After the second testing, the fourth year students had the following results: 4 words were produced only by one person (3\%), 5 words - by 6 persons (20\%), 6 words - by 8 persons (27\%), 7 words - by 7 persons (23\%), 8 words - by 5 persons (17\%), 9 words - by 3 persons (10\%) (Table 4).

Table 4. Number of words remembered by the first and the fourth year students during the second short-term memory capacity testing

\begin{tabular}{|c|c|c|}
\hline $\begin{array}{c}\text { Number of words } \\
\text { remembered by } \\
\text { the students }\end{array}$ & The first year students & $\begin{array}{c}\text { The fourth year } \\
\text { students }\end{array}$ \\
\hline 4 words & 3 persons $(9 \%)$ & 1 persons $(3 \%)$ \\
\hline 5 words & 8 persons $(25 \%)$ & 6 persons $(20 \%)$ \\
\hline 6 words & 9 persons $(28 \%)$ & 8 persons $(27 \%)$ \\
\hline 7 words & 8 persons $(25 \%)$ & 7 persons $(23 \%)$ \\
\hline 8 words & 4 persons $(12 \%)$ & 5 persons $(17 \%)$ \\
\hline 9 words & 0 persons & 3 persons $(10 \%)$ \\
\hline
\end{tabular}

In sum, the first year students showed such results: 3 persons $(9 \%)$ showed the low level of short-term memory, 25 persons $(78 \%)$ - the middle level, and 4 persons $(12 \%)-$ the high level. After the second testing of the fourth year students the low level of short-term memory was demonstrated only by one person $(3 \%)$, the middle level by 21 persons $(70 \%)$ and the high level - by 8 persons
(27\%) (Table 5).

Table 5. The comparison of the capacity of short-term memory of the first and fourth year students in the second testing (\%)

\begin{tabular}{|c|c|c|c|}
\hline \multirow{2}{*}{ Group of students } & \multicolumn{3}{|c|}{ Levels of short-term memory } \\
\cline { 2 - 4 } & Low & Middle & High \\
\hline The first year students & $9 \%$ & $78 \%$ & $12 \%$ \\
\hline The fourth year students & $3 \%$ & $70 \%$ & $27 \%$ \\
\hline
\end{tabular}

In comparison with the first testing, the decrease in the number of the first year students with the low level of short-term memory for $10 \%$ is seen. At the same time, the increase in the number of the first year students that showed the middle and high levels of short-term memory in $7 \%$ and $3 \%$ respectively, is seen (Table 6).

Table 6. The comparison of levels of short-term memory of the first year students in the first and the second testing $(\%)$

\begin{tabular}{|c|c|c|c|}
\hline \multirow{2}{*}{$\begin{array}{c}\text { Stages of the first year students } \\
\text { testing }\end{array}$} & \multicolumn{3}{|c|}{ Levels of short-term memory } \\
\cline { 2 - 4 } & Low & Middle & High \\
\hline The first testing & $19 \%$ & $72 \%$ & $9 \%$ \\
\hline The second testing & $9 \%$ & $79 \%$ & $12 \%$ \\
\hline
\end{tabular}

At the same time, the second testing showed the decrease in the number of the fourth year students with the low level of short-term memory for $4 \%$, as well as the decrease in the number of the students with the middle level of short-term memory for $6 \%$. Meanwhile, the increase in the number of the fourth year students with high levels of short-term memory in $10 \%$ is seen (Table 7).

Table 7. The comparison of levels of short-term memory of the fourth year students in the first and the second testing (\%)

\begin{tabular}{|c|c|c|c|}
\hline \multirow{2}{*}{$\begin{array}{c}\text { Stages of the fourth year students } \\
\text { testing }\end{array}$} & \multicolumn{3}{|c|}{ Levels of short-term memory } \\
\cline { 2 - 4 } & Low & Middle & High \\
\hline The first testing & $7 \%$ & $76 \%$ & $17 \%$ \\
\hline The second testing & $3 \%$ & $70 \%$ & $27 \%$ \\
\hline
\end{tabular}

\section{Discussion}

This method of random production, as an experimental paradigm, has been proven to be effective by subsequent studies, since becoming popular in the 1960s. At that time, some researches in which the respondents had to produce 10,20 or 30 words immediately or after 15 second pauses, were also conducted [13]. Soon, some significant conclusions of random production were determined: the longer the list, the less the possibility of reproducing every word; in each list some first objects (the effect of "first come, first served") are better reproduced, despite the length of list and some last objects are produced 
without mistakes (the effect "last objects", that disappears upon a condition of a short delay) [4; 13].

During the study of short-term memory capacity of the students of the Institute of Philology of National Taras Shevchenko University of Kyiv, the effect of priority and the effect of "last objects" were proven. The study confirmed the higher probability of recollecting some first words in comparison with words in the middle of the list, because 46 students ( $74 \%$ ) recreated two first words from the pronounced list of words (une chaise, une maison during the first testing and une tasse, un lit during the second testing).

Good memorizing of several last words from the list was also shown: 53 students (85\%) wrote two last words from the list (une fleur, un stylo during the first testing and une lampe, un café during the second testing). The effect of "last objects" is not limited only to short-time memory, it starts with the fact that some last acts are better memorized, that is to say this effect can take place in long-term memory as well, and such tendency to keep some last objects in long-term memory plays an important role in time and space orienting [13].

The majority of students (41 persons $-66 \%)$ produced at least one out of two words that were different from other words and came from words denoting objects of common use, so the chances to memorize them were greater [4], those words were une microscope, un pirate during the first testing and un pont, une guitar during the second testing. In addition, frequent memorising of words that create pairs was observed (une table - une chaise, un stylo - un cahier during the first testing and une tasse - un café, un lit - un coussin during the second testing) - 34 persons $(55 \%)$ produced at least one pair of words (Table $8)$.

Table 8. Features of the words most often played by students during testing

\begin{tabular}{|c|c|c|}
\hline $\begin{array}{c}\text { Words remembered } \\
\text { by the students }\end{array}$ & $\begin{array}{c}\text { Number of the first } \\
\text { and fourth year } \\
\text { students }\end{array}$ & $\begin{array}{c}\text { Percent of the } \\
\text { general number of } \\
\text { students }\end{array}$ \\
\hline $\begin{array}{c}\text { Two first words from } \\
\text { the list }\end{array}$ & 46 students & $74 \%$ \\
\hline $\begin{array}{c}\text { Two last words from } \\
\text { the list }\end{array}$ & 53 students & $85 \%$ \\
\hline $\begin{array}{c}\text { One word that is out } \\
\text { or the category of } \\
\text { other words }\end{array}$ & 41 students & $66 \%$ \\
\hline $\begin{array}{c}\text { Words that form } \\
\text { pairs }\end{array}$ & 34 students & $55 \%$ \\
\hline
\end{tabular}

The capacity of short-term memory can be increased by active training. The regular and focused practice of memorization and production can help to increase the capacity and duration of short-term memory [4]. The brain memorizes more information if its properly trained. Due to this, warming up students' brains before certain cognitive tasks improves their performance. "Learning by heart" activity as a class warm-up is, beyond any doubt, a splendid opportunity to train memory [18]. The well-developed short-term memory can improve the effectiveness of accomplishing work tasks and influence a person's ability to solve some problems in a quick and efficient way and to acquire knowledge easily [3]. Memory training has a positive impact on the ability of a person to concentrate and increases their level of attention and the speed of information processing [5].

The first testing of short-term memory capacity of the first and fourth year students who learn French showed that 8 persons $(13 \%)$ have low level of short-term memory capacity, 46 persons (74\%) - middle level, and 8 persons $(13 \%)$ - high level. The second testing of the same group of respondents demonstrated such results: low level of short-term memory capacity -4 persons $(6 \%)$, middle level -46 persons (74\%) and high level- 12 persons (20\%) (Table 9).

Thus, even if the percentage of students with the middle level of short-term memory capacity did not change in the second testing comparing to the first testing, the percentage of students with the low level capacity decreased in $7 \%$, and the percentage of students that have high level of short-term memory increased in $7 \%$, so that the students showed the improvement of short-term memory capacity after longstanding short-term memory trainings.

Table 9. The comparison of short-term memory capacity of the first and the forth year students during the first and the second testing $(\%)$

\begin{tabular}{|c|c|c|c|}
\hline \multirow{2}{*}{$\begin{array}{c}\text { Stages of the first and fourth year } \\
\text { students testing }\end{array}$} & \multicolumn{3}{|c|}{ Levels of short-term memory } \\
\cline { 2 - 4 } & Low & Middle & High \\
\hline The first testing & $13 \%$ & $74 \%$ & $13 \%$ \\
\hline The second testing & $6 \%$ & $74 \%$ & $20 \%$ \\
\hline
\end{tabular}

During the first testing, more first year students than fourth year students had a low level of short-term memory (19\% compared to $7 \%$ respectively), meanwhile the number of students with middle level of short-term memory was approximately the same in groups of first year and fourth year students (72\% compared to $76 \%$ respectively). The fact that almost the same number of students at the beginning of the experiment could reproduce the number of words that corresponded to the middle level of short-term memory indicates that the words were chosen in such a way that students with different levels of language training could reproduce them. This proves that the authors' technique is effective. So, the analysis of the data after the first testing revealed a slight difference between the short-term memory capacity of students with different levels of language training.

The results of the second test showed that the number of first and fourth year students with middle and high levels of short-term memory capacity was not significantly different (first year students - 91\%, fourth year students - 97\%). Therefore, memory testing after the training period showed approximately the same increase in short-term memory 
capacity for both first year and fourth year students.

\section{Conclusions}

Short-term memory is an integral part of a process of memorization that involves an endurable saving of learned information. The capacity of short-term memory can be tested with the help of the method of random reproduction, when a group of people is given a list of 10 words that they have to listen to and then to write the words they could remember in any order. The testing of the short-term memory capacity was carried out with a group of 62 university students that learn French.

The research consisted of several steps: the first testing of short-term memory capacity; processing the results of the first testing; regular training of short-term memory with using certain special tasks; the second testing of the capacity of short-term memory; processing the results of the second testing; comparing the results of both tests, and drawing conclusions. For the first and second testing, 10 French words were chosen, taking into account their usage, imagery, the effect of phonological similarity and the effect of the length of the word. During testing, the physical state of respondents, their age and speed of reading were also taken into consideration.

The first testing demonstrated that more first year students than fourth year students had a low level of short-term memory capacity (19\% compared to $7 \%$ respectively), meanwhile the number of students with middle level of short-term memory capacity was approximately the same in groups of the first and fourth year students (72\% compared to $76 \%$ respectively). During the first testing, $9 \%$ of first year students and $27 \%$ of fourth year students had a high level of short-term memory capacity.

For short-term memory training, students were offered two types of tasks: the exact repetition of different lines of poems of French writers and reproduction of some short humorous stories or anecdotes. Such tasks not only contributed to memory improvement, but also developed the cultural and linguistic knowledge of students, by means of poems and short stories from the literature and culture of French-speaking countries while improving their knowledge of French.

The experiment showed that short-term memory training of students is effective, as demonstrated by the results: the number of students that had a low level of short-term memory decreased by $7 \%$ while the number of students that had a high level of short-term memory increased by $7 \%$.

The results of the second testing showed that the number of first and fourth year students with middle and high levels of short-term memory capacity was not significantly different (first year students $-91 \%$, fourth year students 97\%). Thus, memory testing after the training period showed approximately the same increase in short-term memory capacity for both first and fourth year students.

The second testing showed a decrease in the number of students with low level of short-term memory capacity in both groups (first year students - from $19 \%$ to $9 \%$, fourth year students - from $7 \%$ to $3 \%$ ). At the same time, the testing demonstrated an increase of the number of first year students with middle level of short-term memory capacity (72\% after the first testing and $79 \%$ after the second testing), and a slightly higher percentage of students with high level of short-term memory capacity ( $9 \%$ after the first testing and $12 \%$ after the second testing). The testing showed a decrease in the number of fourth year students with middle level of short-term memory (from $76 \%$ after the first testing to $70 \%$ after secondary testing) and an increase in the number of students with high level of short-term memory (from 17\% after the first testing to $27 \%$ after the second testing). Higher percentages of fourth year students with high level of short-term memory during the first and the second testing, compared to first year students, may indicate a positive impact of three years of university studies on memory development.

Therefore, it was proved that regular short-term memory training has a positive impact on increasing its capacity and improves the reproduction of information which students perceive by ear, and that influences positively on the development of interpreting skills.

The results of the research can be used as a base for future studies on the effective methods and techniques of short-term memory training for teaching future interpreters.

\section{Disclosure Statement}

No author has any financial interest or received any financial benefit from this research.

\section{Conflict of Interest}

The authors state that there is no conflict of interest.

\section{REFERENCES}

[1] Plato. The Dialogues of Plato, Vol. 4 Retrieved from http://oll.libertyfund.org/titles/plato-dialogues-vol-4-parme nides-theaetetus-sophist-statesman-philebus, 2018.

[2] Ye.Ye. Vasylieva, V.Yu. Vasyliev. Superpamiat ili kak zapomnit chtoby vspomnit. Ekzameny i kariera bez problem [Supermemory or how to memorise to remember. Exams and career without problems], Moscow, Russia: Astrel, AST, 2007 [in Russian].

[3] H. Eichenbaum. Learning and memory, New York, London: W.W. Norton \& Company, 2008. 
[4] Paul Sloane. How to be a Brilliant Thinker: Exercise Your Mind and Find Creative Solutions, London, Philadelphia: Kogan Page, 2010.

[5] Miguel Ángel Vergara, José María Bea González. Consigue una memoria de elefante: técnicas, ejercicios y trucos infalibles, Barcelona, Spain: Ediciones Temas de Hoy, 2017 [in Spanish].

[6] A. Kalinina. Kak zastavit pamiat rabotat [How to make memory work], Moscow, Russia: AST, 2007. [in Russian].

[7] Nelson Cowan. What are the differences between long-term, short-term, and working memory? Retrieved from https://www.ncbi.nlm.nih.gov/pmc/articles/PMC2657600/, 2009.

[8] Geoff Watts. The amazing brain of the real-time interpreters, Retrieved fromhttp://www.bbc.com/future/story/20141117 -the-ultimate-multi-taskers, 2014.

[9] S.B. Fokin. Rol kilkisnykh parametrisv pry vyshkoli usnykh perekladachiv [The role of quantitative parameters in the training of oral interpreters], Visnyk Kyivskogo natsionalnogo universytetu imeni Tarasa Shevchenka. Inozemna filologia - Bulletin of National Taras Shevchenko University of Kyiv. Foreign philology, 45, 15-18, 2012. [in Ukrainian].

[10] I.D. Yunyk. Pamiat yak factor formuvannia fakhovykh cognityvnykh umin perekladachiv [Memory as a factor for formation of professional cognitive skills of translators], Naukovy visnyk Melitopolskogo derzhavnogo pedagogichnogo universytetu - Scientific bulletin of Melitopol State Pedagogical University, 1, 166-171, 2015. [in Ukrainian].

[11] Paul Verlaine. Liste des poèmes de l'auteur, Retrieved from http://poesie.webnet.fr/lesgrandsclassiques/poemes/paul_v erlaine/paul_verlaine.html, 2009. [in French].

[12] Suzanne Julliard. Anthologie de la poésie française, Paris, France: Editions de Fallois, 2002. [in French].

[13] A. Baddley, M. Eysenck, M. Anderson. Pamiat [Memory], St. Petersburg, Russia: Piter, 2011. [in Russian].

[14] L.G. Podoliak, V.I. Yurchenko. Psykhologiia vyshchoyi shkoly [Psychology of higher school], Kyiv, Ukraine: Karavela, 2014. [in Ukrainian].

[15] Etychnyy codeks universytetskoyi spilnoty [Ethical code of the University community], Retrieved fromhttp://www.uni v.kiev.ua/pdfs/official/ethical-code/Ethical-code-of-the-uni versity-community.pdf, 2017. [in Ukrainian].

[16] Kendra Cherry. What is short-term memory and how long does it last? Retrieved from https://www.verywell.com/ what-is-short-term-memory-2795348, 2017.

[17] V.V. Voloshyna, L.V. Volynska, S.O. Stavytska, O.V. Temruk. Zagalna psykhologiia [General psychology], Kyiv, Ukraine: Karavela, 2008. [in Ukrainian].

[18] Maiia Karpushyna, Ihor Bloshchynskyi, Alona Nakonechna, Kateryna Skyba. "Creating Meaningful Foreign Language Environment by Means of Content-based Starters" Universal Journal of Educational Research 7.12 (2019) 2710 - 2716. doi: 10.13189/ujer.2019.071219. 